US Army Corps

of Engineers

Waterways Experiment

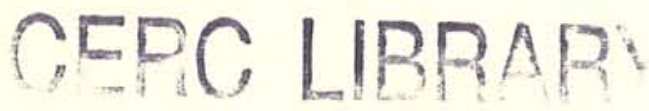

Station

\title{
Potential Toe Scour and Wave Reflection at Revetments
}

by Ernest R. Smith

Approved For Public Release; Distribution Is Unlimited
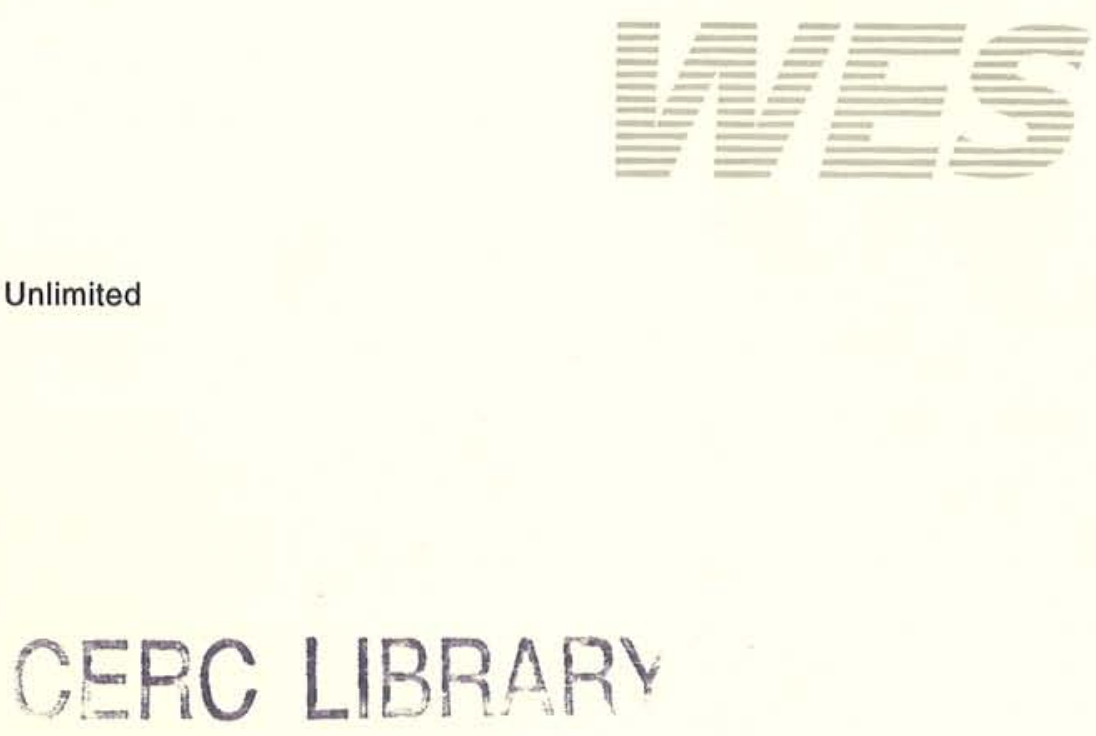

Prepared for Headquarters, U.S. Army Corps of Engineers 
The contents of this report are not to be used for advertising, publication, or promotional purposes. Citation of trade names does not constitute an official endorsement or approval of the use of such commercial products. 


\section{Potential Toe Scour and Wave Reflection at Revetments}

by Ernest R. Smith

U.S. Army Corps of Engineers

Waterways Experiment Station

3909 Halls Ferry Road

Vicksburg, MS 39180-6199

\section{Final report}

Approved for public release; distribution is unlimited 


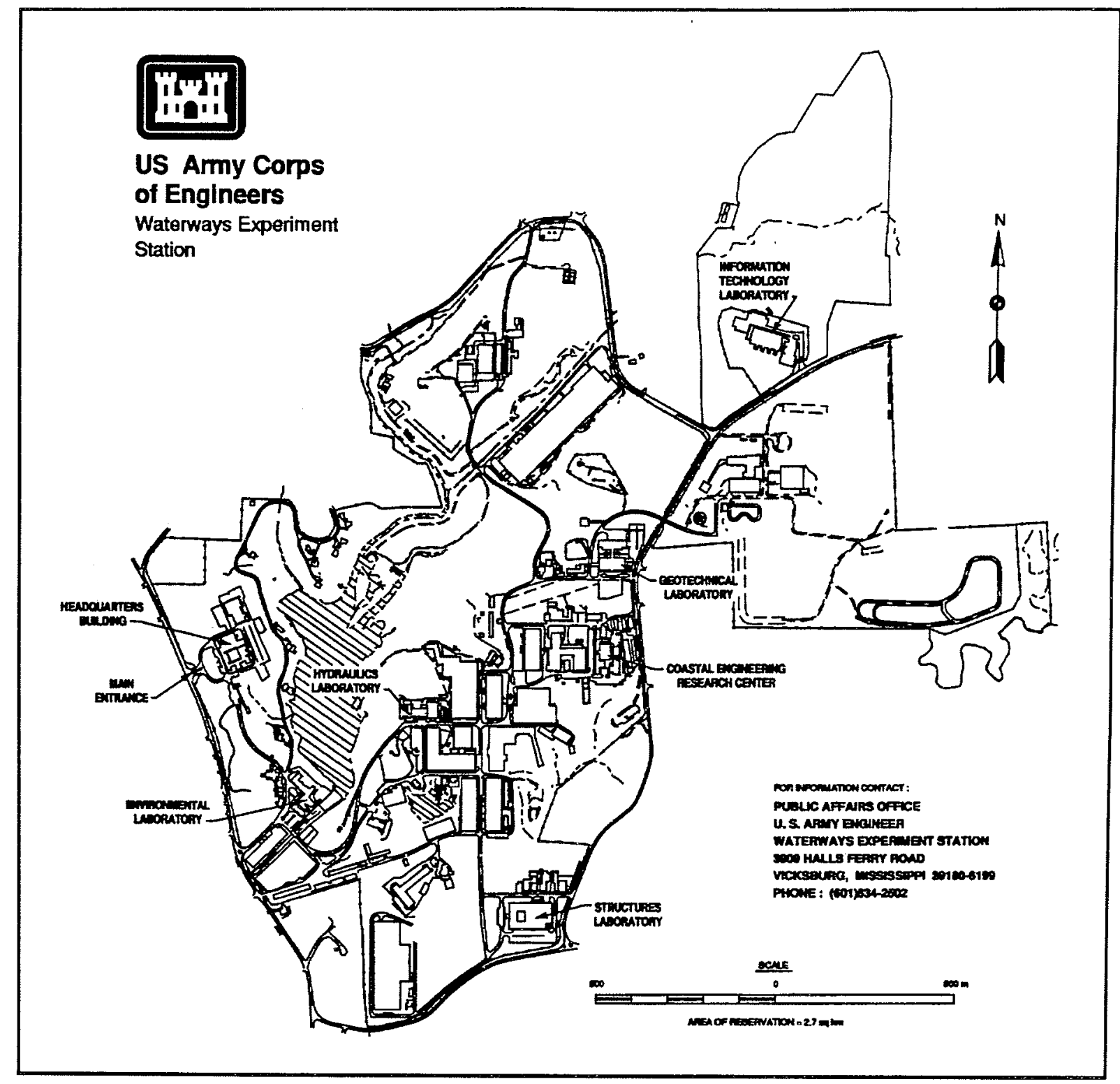

\section{Waterways Experiment Station Cataloging-in-Publication Data}

Smith, Ernest R.

Potential toe scour and wave reflection at revetments / by Ernest R. Smith ; prepared for U.S. Army Corps of Engineers.

29 p. : ill. ; $28 \mathrm{~cm}$. - (Miscellaneous paper ; CERC-96-2) Includes bibliographic references.

1. Scour (Hydraulic engineering) - Estimates. 2. Ocean waves. 3. Embankments. I. United States. Army. Corps of Engineers. II. U.S. Army Engineer Waterways Experiment Station. III. Coastal Engineering Research Center (U.S. Army Engineer Waterways Experiment Station) IV. Title. V. Series: Miscellaneous paper (U.S. Army Engineer Waterways Experiment Station) ; CERC-96-2.

TA7 W34m no.CERC-96-2 


\section{Contents}

Preface $\ldots \ldots \ldots \ldots \ldots \ldots \ldots \ldots \ldots \ldots \ldots \ldots$

1 -Introduction $\ldots \ldots \ldots \ldots \ldots \ldots \ldots \ldots \ldots \ldots \ldots \ldots \ldots \ldots \ldots \ldots \ldots$

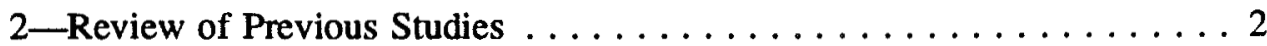

3 -Laboratory Test Design $\ldots \ldots \ldots \ldots \ldots \ldots \ldots \ldots \ldots \ldots \ldots \ldots$

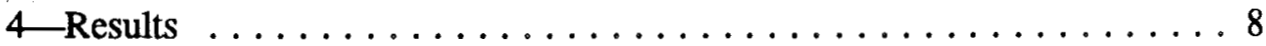

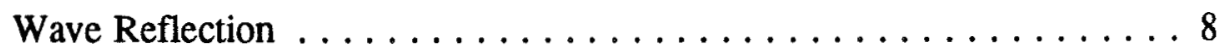

Wave Steepness $\ldots \ldots \ldots \ldots \ldots \ldots \ldots \ldots \ldots \ldots \ldots \ldots$

Relative Depth $\ldots \ldots \ldots \ldots \ldots \ldots \ldots \ldots \ldots \ldots \ldots \ldots$

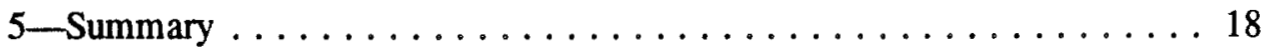

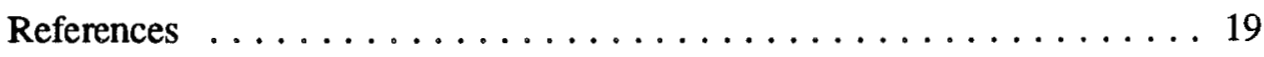

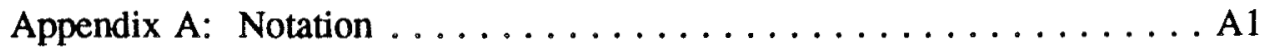

SF 298

\section{List of Figures}

Figure 1. Wave tank used in study, distorted scale $(1 \mathrm{H}=3 \mathrm{~V}) \ldots \ldots \ldots 5$

Figure 2. Reflection coefficient as a function of surf similarity parameter $\ldots \ldots \ldots \ldots \ldots \ldots \ldots$

Figure 3. Offshore-directed bottom velocity as a function of reflection $\ldots \ldots \ldots \ldots \ldots \ldots \ldots$

Figure 4. Offshore-directed bottom velocity versus $K_{r}$ for breaking waves $\ldots \ldots \ldots \ldots \ldots \ldots \ldots$

Figure 5. Offshore-directed bottom velocity versus $H_{d} L_{o} \ldots \ldots \ldots 12$

Figure 6. $\quad+U_{r m s} / C$ as a function of deepwater wave steepness $\ldots \ldots 13$

Figure 7. Offshore-directed bottom velocity versus relative depth . . . 13

Figure $8 . \quad+U_{r m s} / C$ versus relative depth $\ldots \ldots \ldots \ldots \ldots \ldots$

Figure $9 . \quad+U_{r m s} / C$ versus relative depth $\ldots \ldots \ldots \ldots \ldots \ldots$ 
Figure 10. Predicted versus measured nearshore $H_{i}$ using Goda (1975) transformation . . . . . . . . . . . 16

Figure 11. Predicted versus measured $+U_{m s} \ldots \ldots \ldots \ldots \ldots$ 


\section{Preface}

The work described in this report was authorized as part of the Civil Works Research and Development Program by Headquarters, U.S. Army Corps of Engineers (HQUSACE). This report summarizes horizontal bottom velocity and potential toe scour investigations performed under Work Unit 32432, "Design of Revetments and Seawalls," at the Coastal Engineering Research Center (CERC) of the U.S. Army Engineer Waterways Experiment Station (WES). Messrs. John H. Lockhart, Jr., John G. Housley, Barry W. Holliday, and David A. Roellig were HQUSACE Technical Monitors during the study. Ms. Carolyn M. Holmes was the CERC Program Manager.

This study was conducted from May 1991 to October 1995 by Mr. Emest R. Smith. General supervision was provided by Dr. James R. Houston and Mr. Charles C. Calhoun, Jr., Director and Assistant Director of CERC, respectively; and direct supervision was provided by Mr. Claude E. Chatham, Chief, Wave Dynamics Division, and Mr. D. D. Davidson, Chief, Wave Research Branch, CERC. Laboratory tests were conducted by Messrs. Smith and John M. Heggins, Wave Research Branch. Dr. Steven A. Hughes, Wave Dynamics Division, Ms. Jane M. Smith, Coastal Processes Branch, and Mr. Donald L. Ward, Wave Research Branch, provided technical review of this report.

Dr. Robert W. Whalin was Director of WES and COL Bruce K. Howard, EN, was Commander at the time of publication.

The contents of this report are not to be used for advertising, publication, or promotional purpases. Citation of trade names does not constituse an official endorsement or approval of the use of such commercial praducts. 


\section{Introduction}

Scour at the toe of revetments is a serious problem for coastal engineers because it causes the armor layer to slip, damaging the structure. This can render the area landward of the structure vulnerable to storm surge and wave attack. The potential for scour is recognized by coastal engineers, and a common scour protection solution is to place stone at the toe of the revetment. Several studies have been conducted on the subject of toe scour, but many of the results conflict. Suitable protection schemes, specifying size and distance of stone placement, have not been developed.

The purpose of this paper is to present a method for estimating toe scour potential at a reveted slope as characterized by bottom velocity. Wave, water level, and structure parameters are considered. Laboratory tests were conducted on a fixed (nonerodible) bottom, and wave and bottom velocity time series were measured near the toe of a revetment. An assumption is made that scour potential is proportional to the magnitude of the root-mean-square (rms) horizontal velocity in the area of scour. First, a review of previous scour studies is given. Next, the laboratory experiment is described. Lastly, results are presented to correlate representative bottom velocity with relative depth, wave steepness, and reflection. 


\section{Review of Previous Studies}

Numerous studies of scour at seawalls and revetments have been conducted. The results of these studies have shown that maximum scour depth is a function of local sediment size; incident wave height $H_{i}$; wave period $T$; wave steepness; location of the structure in the surf zone or depth at the structure toe $d_{s}$; ratio of depth to wave height at the toe (relative depth) $d_{s} / H_{i}$; wave reflection coefficient $K_{r}$; beach slope $m$; and structure slope $\theta$. In addition, Dorland (1940) observed in laboratory wave tank tests that wave action alone did not cause scour in front of a seawall, but waves may place sediment into suspension to be transported by currents. The following paragraphs summarize some of the results obtained on toe scour. More extensive reviews of scour at seawalls can be found in Powell (1987) and Kraus (1988).

Earlier work indicated scour depth to be directly proportional to wave height. Russel and Inglis (1953) observed that maximum scour depth of a vertical wall was equal to the deepwater wave height $H_{o}$. Sawaragi (1966) also found scour depth to be proportional to $H_{o}$ in tests with sloping structures; however, Sawaragi concluded maximum scour depth was 60 percent of the deepwater wave height. Xie (1985) noted that depth of scour was directly proportional to incident wave height and inversely proportional to the water depth-to-wave-length ratio $d_{s} / L$ at the toe of a vertical structure. Xie found that in shallow water, $d_{s} L \approx 0.05$, maximum scour depth was equal to the incident wave height. Because wave-induced velocities are proportional to wave height, scour depth should also be proportional to horizontal bottom velocity. It should be noted that these early results stem from two-dimensional tests using regular waves.

Several investigators found scour to be a function of the reflection coefficient; however, the results conflict. Herbich, Murphy, and Van Weele (1965) generated nonbreaking waves on a flat sand bed fronting an inclined wall. They found scour increased with $K_{r}$ but did not increase for high values of reflection. Herbich and Ko (1968) continued the work of Herbich, Murphy, and Van Weele, and they stated that scour was probably due to the difference in reflection coefficients of nonbreaking and breaking waves. Song and Schiller (1977) determined scour increased for low values of $K_{r}$, and concluded if reflection was small, waves broke at the wall and the turbulence 
created by the breaking waves caused greater scour than if reflection was high and waves did not break. Sawaragi (1966) conducted laboratory tests to determine the relationship between scour and reflection. In contrast to the results of Song and Schiller, Sawaragi found accretion occurred at a seawall if $K_{r}$ was less than 0.25 and erosion occurred for values above 0.25 . Eckert (1983) reviewed geotechnical and hydraulic criteria for design of toe aprons and also concluded that scour will occur if $K_{r}$ is greater than 0.25 .

Sato, Tanaka, and Irie (1968) found from laboratory and field tests with vertical and sloping structures that scour depth varied with wave steepness. They found minimum scour occurred for steep waves, but maximum scour occurred under storm conditions in which deepwater wave steepness $H_{\delta} / L_{o}$ was in the range of 0.02 to 0.04 .

The location of a structure relative to the surf zone was found to influence scour depth. In wave tank tests with a vertical wall, Sato, Tanaka, and Irie (1968) found maximum scour occurred if the wall was placed at the shoreline or slightly shoreward of the breakpoint. Chestnutt and Schiller (1971) varied seawall location in laboratory tests fronting sloping beaches. They defined the "critical region" for scour as one half to two thirds the surf zone width from the shoreline. If the seawall was located shoreward of this region, accretion occurred. In wave tank tests with a vertical wall and a compound sand slope, Hotta and Marui (1976) demonstrated scour depths were minimum at the break point and maximum at 38 percent of the distance from the shoreline to the break point. Song and Schiller found maximum scour occurred for a vertical wall placed at the plunge point and minimum scour occurred if the wall was located at the break point. Kraus (1988) concluded from a review of literature pertaining to seawalls that maximum scour depth occurred if the wall was located in the middle to outer third of the surf zone.

Powell (1987) reanalyzed results of Ichikawa (1967) and Hotta and Marui (1976) and found maximum scour occurred in these tests if the unscoured water depth at the toe of the wall was 50 to 60 percent greater than the deepwater wave height. 


\section{Laboratory Test Design}

The present study was conducted to determine the wave, water-level, and structure conditions that have the greatest potential to cause scour at the toe of a sloping revetment. For the tests, the hypothesis of Dorland (1940) that sediment is put into suspension by waves and is transported by currents was assumed. Therefore, the purpose of the experiments was to determine the conditions which produce maximum horizontal bottom velocities at the toe of a revetment.

The bottom topography fronting a revetment or seawall is influenced by incident wave conditions, and incident waves in tum are influenced by bottom topography. If incident waves were unchanging, the waves and movable bottom would interact until a steady state condition was reached and an equilibrium profile formed. However, in nature, waves vary and a steady-state condition is never reached. To control, and also quantify, the incident wave conditions that cause maximum scour velocities, the bottom boundary in these tests was fixed. The assumption was made that maximum scour for any sediment size would occur where the bottom velocities produced by incident wave conditions were maximum.

Test conditions were chosen based on a review of literature covering laboratory, field, and theoretical studies pertaining to the development of maximum scour. These conditions include a range of wave heights (wave steepnesses between 0.02 and 0.04 (Sato, Tanaka, and Irie 1968)), a range of wave and water level conditions to produce a variety of surf zone widths and revetment locations within the surf zone, and ratios of wave height to water depth at the toe that vary significantly below and above the range of 1.5 to 1.6 (Powell 1987). Additionally, the slope and porosity of the revetment were varied, to produce different reflection surfaces for similar wave conditions. A total of 120 tests were conducted, which included 30 irregular wave conditions, two reveted slopes, and two porosities for each slope. Wave conditions consisted of three peak wave periods, and five zero-moment wave heights tested with two water depths. Test variables for the study are shown in Table 1.

Tests were conducted in a $0.91-\mathrm{m}$-wide, 45.7-m-long, and 0.91-m-deep glass-walled wave tank (Figure 1). The bottom configuration included an 11-m flat bottom, a 3.4-m-long section at a 1:20 slope, and a 21.6-m-long section at a 1:100 slope. The upper section of the 1:100 slope was divided 


\begin{tabular}{|c|c|c|c|c|c|}
\hline Cace & $\begin{array}{l}d s \\
(c m)\end{array}$ & $\begin{array}{l}\text { Armor } \\
\text { Type }\end{array}$ & $\begin{array}{l}\text { Rovotment } \\
\text { Siope }\end{array}$ & $\begin{array}{l}T \\
(\sec )\end{array}$ & $\begin{array}{l}H^{\prime} \\
(\mathrm{cm})\end{array}$ \\
\hline 1 & 16.8 & Stone & 2.0 & $1.5,2.0,2.5$ & $10.4,11.6,13.7,14.9,16.5$ \\
\hline 2 & 16.8 & Stone & 3.5 & $1.5,2.0,2.5$ & $10.4,11.6,13.7,14.9,16.5$ \\
\hline 3 & 16.8 & Dolos & 2.0 & $1.5,2.0,2.5$ & $10.4,11.6,13.7,14.9,16.5$ \\
\hline 4 & 16.8 & Dolos & 3.5 & $1.5,2.0,2.5$ & $10.4,11.6,13.7,14.9,16.5$ \\
\hline 5 & 25.9 & Stone & 2.0 & $1.5,2.0,2.5$ & $10.4,11.6,13.7,14.9,16.5$ \\
\hline 6 & 25.9 & Stone & 3.5 & $1.5,2.0,2.5$ & $10.4,11.6,13.7,14.9,16.5$ \\
\hline 7 & 25.9 & Dolos & 2.0 & $1.5,2.0,2.5$ & $10.4,11.6,13.7,14.9,16.5$ \\
\hline 8 & 25.9 & Dolos & 3.5 & $1.5,2.0,2.5$ & $10.4,11.6,13.7,14.9,16.5$ \\
\hline
\end{tabular}

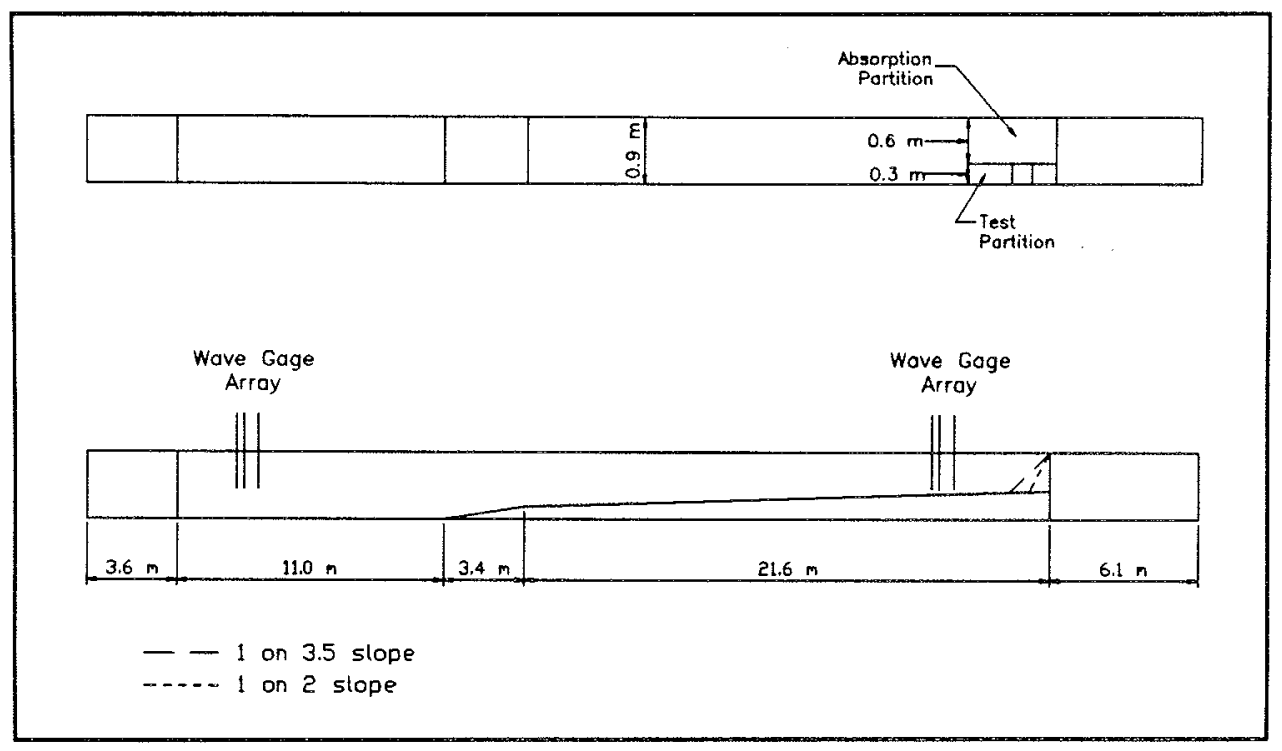

Figure 1. Wave tank used in study, distorted scale $(1 \mathrm{H}=3 \mathrm{~V})$

into two compartments to reduce the effect of re-reflected waves. A revetment was constructed of stone or dolos placed on an underlayer, which rested on an impermeable board in a $0.30-\mathrm{m}$-wide partition of the tank. The revetment was built sufficiently high to avoid overtopping of the structure at both water levels. Wave absorber was placed in the $0.61-\mathrm{m}$-wide partition on the opposite side of the divider from the revetment. Irregular waves were produced by an electronically controlled hydraulic system, which drove a piston-type wave board. Water surface elevation was measured with six capacitance-type gauges, which were arranged to facilitate calculation of reflection coefficients 
near the wave board in the horizontal section of the tank and near the structure using the method of Goda and Suzuki (1976) (see Figure 1).

Fifteen irregular wave conditions (five zero-moment wave heights and three peak periods) were selected to encompass relative depths and wave steepnesses specified in the literature for having the potential for scour. Reflection of incident wave conditions was altered in the tests by varying structure slope (1V:3.5H and $1 \mathrm{~V}: 2 \mathrm{H}$ ), and by varying armor layer (stone and dolos).

Although dolosse are not normally used as a revetment armor layer, they were used in the present study to vary porosity and texture relative to stone. Position of the structure relative to wave breaking was altered by varying wave height, period, and still-water level. Combination of the test variables resulted in 120 test conditions.

The study objective was to measure horizontal velocities in the toe region where scour would affect stability of the revetment. Sand in the region of the toe often is armored with a stone toe berm. Lee $(1970,1972)$ and, more recently, Markle (1989) conducted research on toe protection. Both Lee and Markle based the toe stone weight on the empirically derived equation of Hudson (1961):

$$
W=\frac{\gamma_{r} H_{d}^{3}}{K_{d}\left(S_{r}-1\right)^{3} \cot \theta}
$$

in which $W$ is the mean weight of the stable individual armor unit, $\gamma_{r}$ is the specific weight of the armor unit, $H_{d}$ is the design wave height at the structure, $K_{d}$ is the stability coefficient which varies in part with the type of armor unit, $S_{r}$ is the specific gravity of the armor unit relative to the water it is placed in, and $\theta$ is the angle of the structure slope measured in degrees from the horizontal plane. Lee recommended that toe stone $W_{\text {toe }}$ should be 30 percent of $W$ and placed for a length of four to six stone widths, whereas Markle recommends $W_{\text {toe }}$ be 10 percent of the armor weight placed at a minimum of three stone widths. Toe berm width $B$ can be calculated from the Shore Protection Manual (1984):

$$
B=n_{s} k_{\delta}\left(\frac{W_{\text {toe }}}{\gamma_{r}}\right)^{\frac{1}{3}}
$$

where $n_{s}$ is the number of stone widths and $k_{\Delta}$ is a layer coefficient dependent upon armor type and shape.

The revetment individual armor weight was determined by inserting test conditions from the present study into Equation 1, using the maximum expected wave height for $H_{d}$, the specific weights of stone and fresh water, and 2 as the recommended value of $K_{d}$ for stone. Toe stone weights were 
determined using the methods of Lee $(1970,1972)$ and Markle (1989), and the values were inserted into Equation 2 to determine berm width. The resultant toe berm widths ranged from 4 to $7 \mathrm{~cm}$. It was expected that scour occurring in this region would be detrimental to structure stability; therefore, horizontal velocity measurements were made at a distance of $5 \mathrm{~cm}$ from the revetment toe. At a nominal scale of $1: 30$, this distance would correspond to about $1.5 \mathrm{~m}$ from the toe in the prototype.

Velocities were obtained using a laser Doppler velocimeter (LDV) positioned near the toe of the revetment. The LDV was operated in backscattering mode, which detects water particle movement through a fringe pattern created by laser light and stores the data on a personal computer. Clean water was used in the tests, but to detect particle velocities with the LDV, it was necessary to place a seeding material, titanium dioxide, into the water to scatter the laser light. It was assumed that the titanium dioxide particles moved at the same velocity as water particles. Both wave and velocity data were collected for sufficiently long records to provide stable velocity time series statistics. 


\section{Results}

\section{Wave Reflection}

The literature showed scour to depend in part on the reflection coefficient. A widely used predictive equation for $K_{r}$ is given by Seelig and Ahrens (1981) as:

$$
K_{r}=\frac{\alpha}{1+\frac{\beta}{\xi^{2}}}
$$

in which $\alpha$ and $\beta$ are empirically derived, dimensionless coefficients, and $\xi$ is the surf similarity parameter given as $\tan \theta /\left(H_{i} / L_{o}\right)^{1 / 2}$. Seelig and Ahrens recommend values of 0.62 and 7.8 for $\alpha$ and $\beta$, respectively, for riprap revetments. Additionally, Allsop (1990) determined $\alpha=0.64$ and $\beta=8.85$ for structures armored with two layers of rock.

Bulk reflection coefficients obtained for the irregular waves in the present study using the nearshore array are shown as a function of $\xi$ in Figure 2. The data follow the trend given by Equation 3, but the coefficients given by Seelig and Ahrens (solid line) and Allsop (dotted line) underpredict measurements for the majority of the data. The coefficients given by Seelig and Ahrens were developed based on regular wave data. In a study investigating wave reflection and velocity at structures, Hughes and Fowler (1995) stated that the equation of Seelig and Ahrens would produce a lower reflection coefficient for a statistically averaged irregular wave height. Many component waves are summed to make an irregular wave condition and are very small in amplitude relative to regular waves. The smaller waves represent higher $\xi$ values, which result in higher reflection coefficients than the $K_{r}$ computed using the recommended $\alpha$ and $\beta$ of Seelig and Ahrens for a statistically averaged irregular wave height. The data shown in Figure 2 support this statement. Therefore, the general form of the Seelig and Ahrens equation was used to predict reflection coefficients for irregular waves using adjusted values of $\alpha$ and $\beta$.

Although Allsop derived coefficients from irregular wave data collected in a wave tank, he stated that simple regression tended to underestimate reflection 


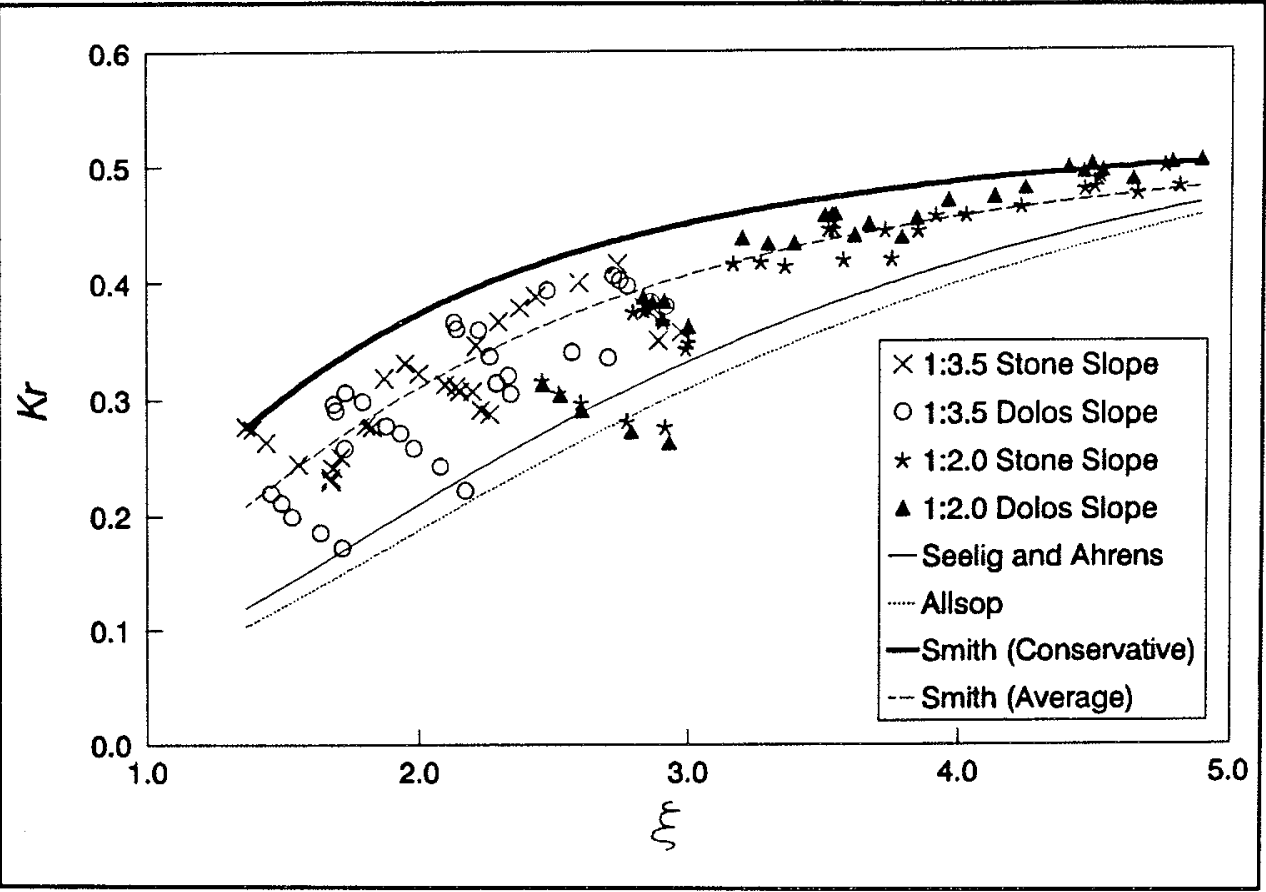

Figure 2. Reflection coefficient as a function of surf similarity parameter

at higher values of $\xi$. Allsop conducted a revised analysis using weighted, higher values of $\xi$ to better describe much of the data.

The upper envelope of reflection data is shown as a dashed line in Figure 2, and was determined using Equation 3 with coefficients of $\alpha=0.54$ and $\beta=1.77$. Coefficients of $\alpha=0.54$ and $\beta=2.95$ gave an average fit to the data, shown as a thick line in Figure 2.

It was assumed that sediment is most likely moved due to peak velocities rather than net velocities. To give an indication of the magnitude of potential transport of sediment away from the toe of revetments, rms bottom velocity of the peaks in the offshore direction $+U_{r m s}$ was plotted versus reflection coefficient in Figure 3. The data scatter can be attributed to different wave periods and heights, water levels, slopes, and porosity of armor units used. Herbich and Ko (1968) stated reflection differed for breaking and nonbreaking waves. A breaking criterion was established for the present data from laboratory observations and irregular wave transformation results of Smith and Kraus (1991). A wave was considered breaking or broken if $H_{i} / d_{s}$ exceeded 0.62 . Figure 4 shows increasing bottom velocity with increasing $K_{r}$ up to some maximum velocity, but decreases slightly with increasing reflection. The maximum velocity occurs at different reflection coefficients for each slope. In general, maximum velocity occurs at $K_{r}=0.38$ for 1:3.5 slope revetments, and in the range of $K_{r}=0.44$ to 0.48 for $1: 2.0$ slopes. At higher reflection coefficients, offshore bottom velocity decreases, which indicates that scour potential decreases. This agrees in general with observations of Herbich, Murphy, and Van Weele (1965), who state that scour ceased at high values of $K_{r}$. 


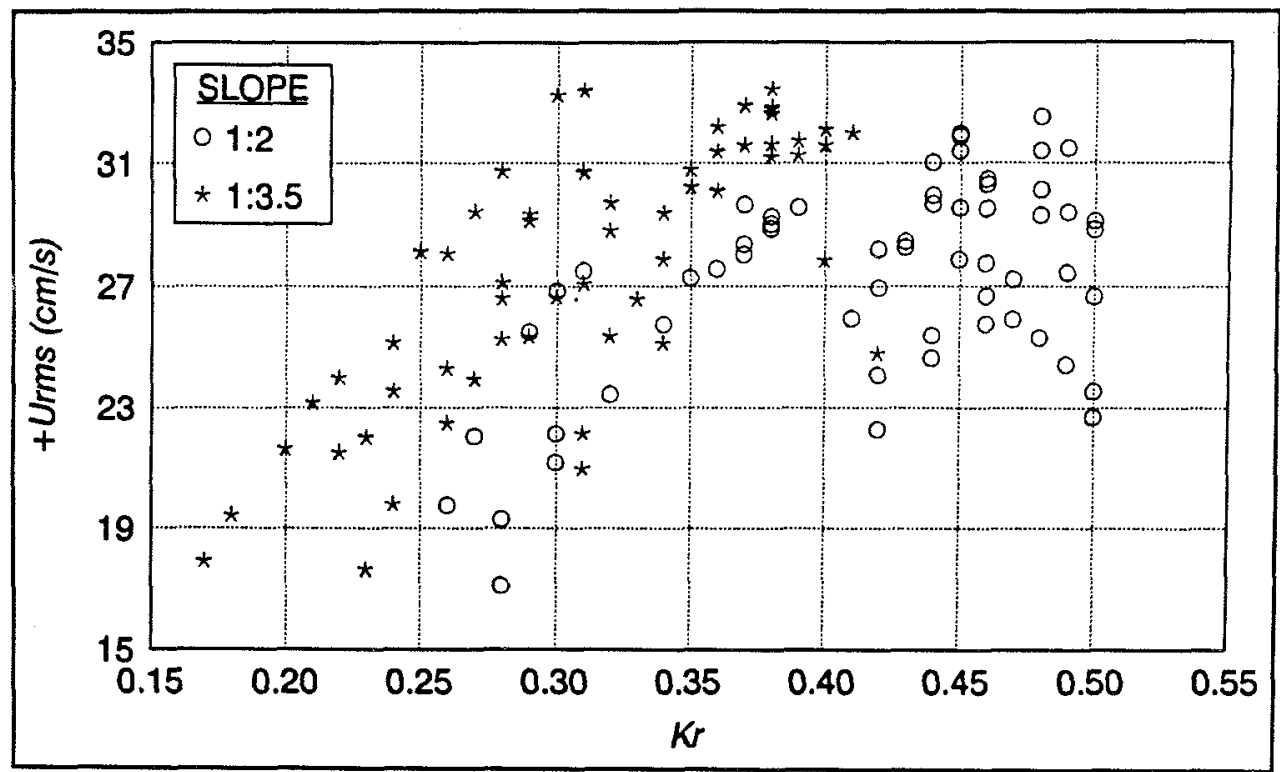

Figure 3. Offshore-directed bottom velocity as a function of reflection

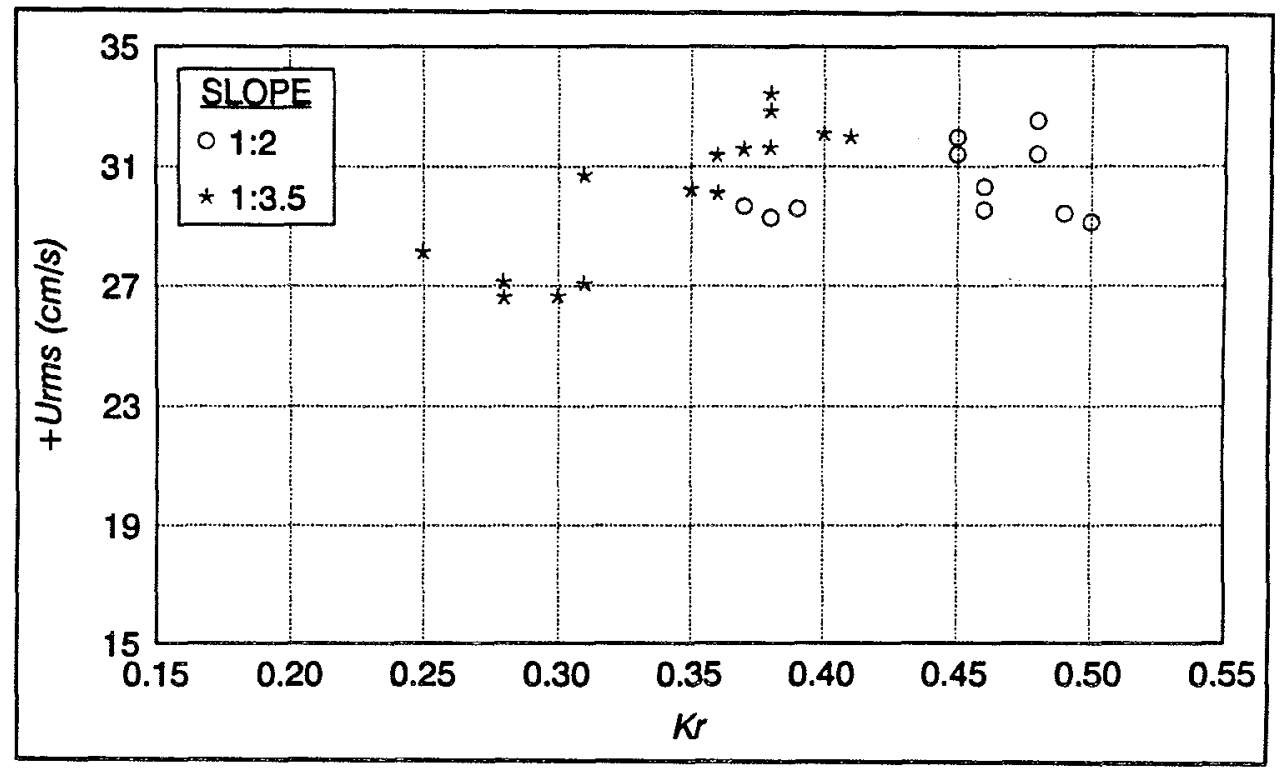

Figure 4. Offshore-directed bottom velocity versus $K_{r}$ for breaking waves

Assuming scour occurs where bottom velocity exceeds some critical value, scour potential at revetments is greatest for breaking wave conditions that produce reflection coefficients less than 0.50 . Reflection coefficients for random waves can be estimated with Equation 3 using $\alpha=0.54$ and $\beta=1.77$ (conservative predictions), or 2.95 (average values). 


\section{Wave Steepness}

Offshore-directed rms bottom velocity at the revetment toe is shown in Figures $5 \mathrm{a}, 5 \mathrm{~b}$, and $5 \mathrm{c}$ as a function of deepwater wave steepness $H_{o} / L_{o}$ for peak wave periods $T_{p}=1.5,2.0$, and $2.5 \mathrm{sec}$, respectively. The figures show that the root-mean square bottom velocity in the offshore direction $+U_{r m s}$ increases for the individual cases of slope, armor layer, and depth. However, because velocity is also proportional to wave length, maximum velocities occur at low steepnesses and show a generally decreasing trend with $H_{d} / L_{o}$. Because bottom velocity is directly proportional to wave height and wave length, the data are scattered. The influence of depth is apparent if $+U_{m s}$ is normalized by wave celerity, $C=L / T$, where $L$ is the wave length associated with peak spectral period $T_{p}$ (Figure 6). Maximum $+U_{\text {mos }} / C$ occurs at lower deepwater wave steepnesses, and each set of constant period and depth data shows increasing velocity with wave height. However, velocities are higher at the shallower water depth for identical wave conditions. Although $+U_{r m s}$ and $H_{o}$ are both normalized by wave length, Figure 6 illustrates that deepwater wave steepness alone is not a good parameter to quantify $+U_{r m s}$ because velocity is directly proportional to both wave height and wave length.

Maximum scour was observed by Sato, Tanaka, and Irie (1968) for storm waves with steepnesses in the range of 0.02 and 0.04 , and minimum scour was observed for steep waves. Laboratory results show that offshore rms velocity decreases with increasing wave steepness, but the highest velocities occurred for minimum deepwater wave steepness. Based on results from the laboratory, observed prototype scour was probably associated with the storm waves breaking near the toe of the structure. The results indicate that scour is not directly related to deepwater wave steepness.

\section{Relative Depth}

Powell (1987) developed a "rule of thumb" that maximum scour occurs at depths 50 to 60 percent greater than the incident wave height, or $d_{s} / H_{i}$ between 1.5 and 1.6. Figure 7 shows $+U_{r m s}$ as a function of relative depth at the toe. Offshore-directed bottom velocity decreases as values of relative depth increase, indicating that horizontal $\mathrm{ms}$ velocity is proportional to wave height, which follows linear wave theory. Data are scattered at lower values of $d_{s} / H_{i}$, which is probably a nonlinear effect of wave breaking. The maximum velocity occurred at a $d_{s} / H_{i}$ of approximately 1.7 ; however, there is much data scatter, and high velocities range between $d_{s} / H_{i}$ values of 1.4 and 1.9. Figure 7 indicates that relative depth alone is not a good indicator of maximum bottom velocity.

If maximum velocities occur at the maximum wave height for a given wave period and slope as Figure 7 suggests, it can be assumed that maximum $\mathrm{ms}$ velocity occurs at incipient wave breaking, because the breaking wave height is the maximum height at the structure toe. If the relative depth values Powell 


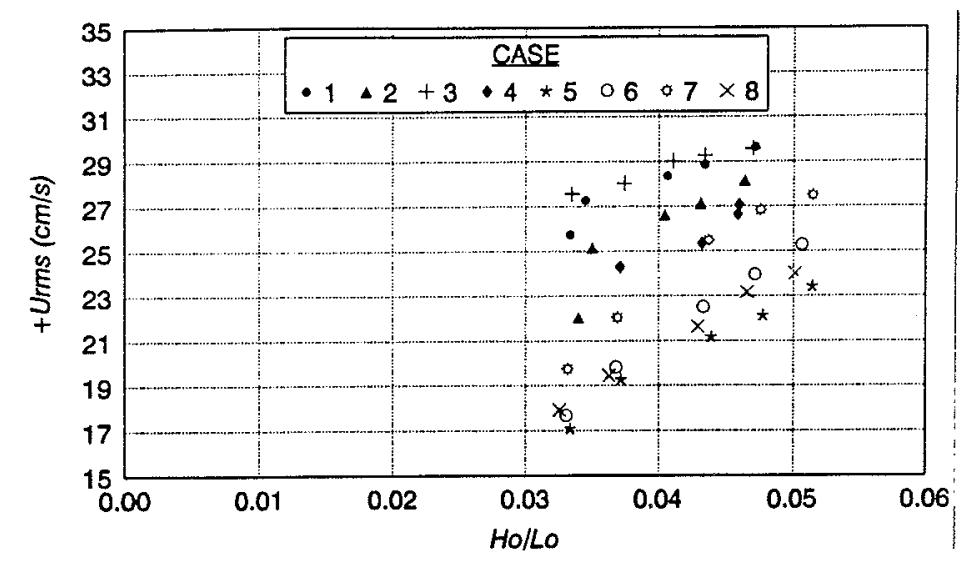

a. $T_{p}=1.5 \mathrm{sec}$

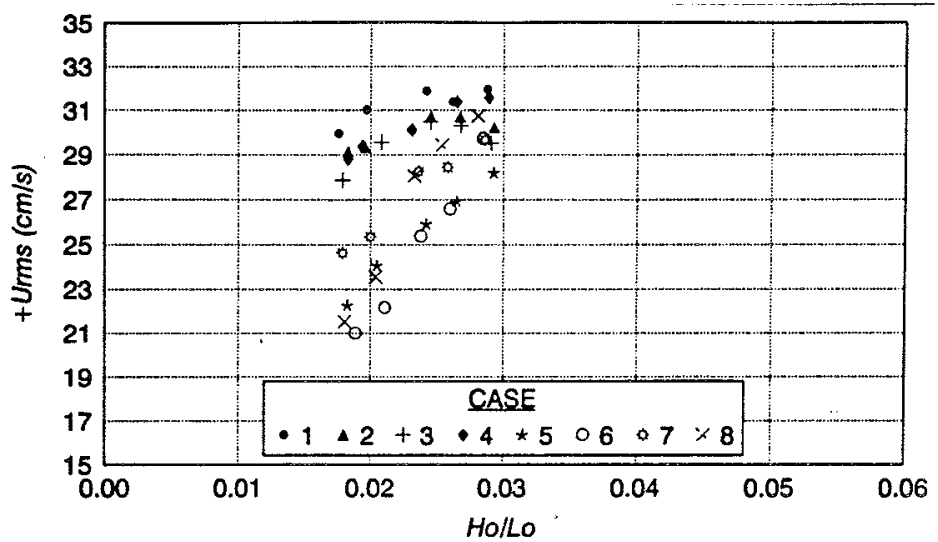

b. $T_{p}=2.0 \mathrm{sec}$

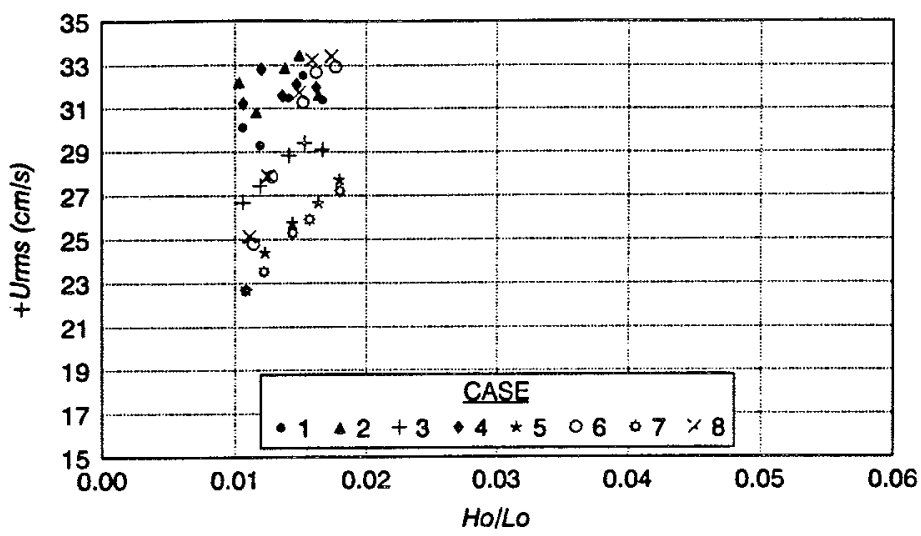

c. $T_{p}=2.5 \mathrm{sec}$

Figure 5. Offshore-directed bottom velocity versus $H_{\delta} L_{0}$ 


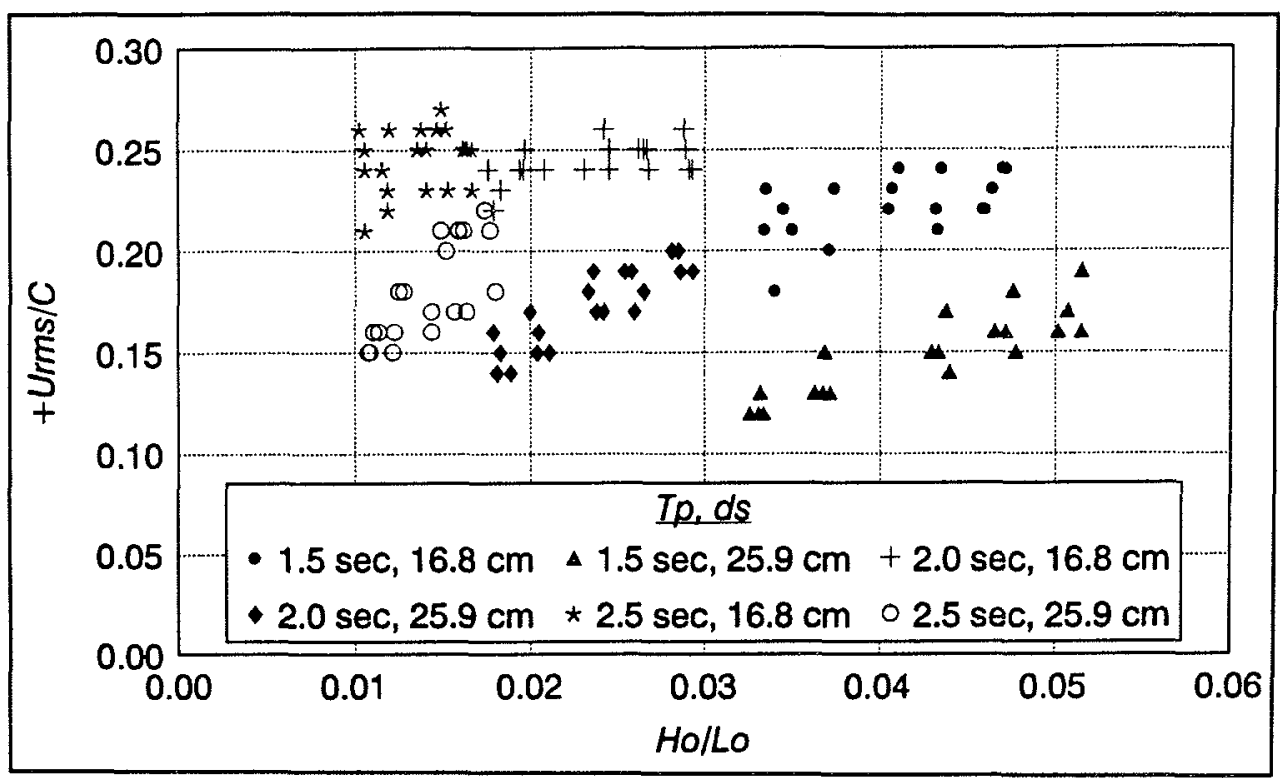

Figure 6. $\quad+U_{r m s} d C$ as a function of deepwater wave steepness

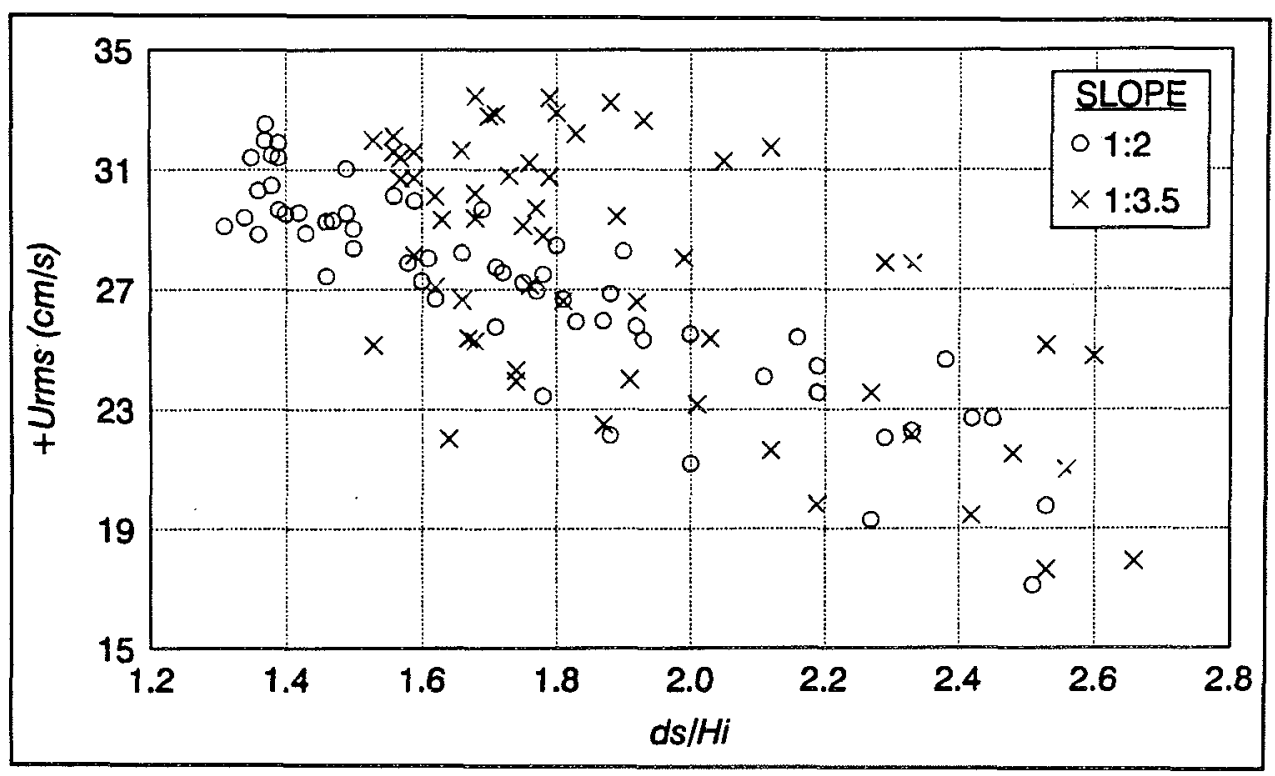

Figure 7. Offshore-directed bottom velocity versus relative depth

suggests are inverted, a wave height to water depth ratio, or breaker depth index, $\gamma_{b}=H_{b} / d_{b}$ is obtained in the range of 0.625 to 0.670 . Smith and Kraus (1991) found breaker indices on gentle, plane sloping beaches to be in this range. However, the effect of a structure's fronting slope on the breaker location and height was not addressed. Powell reanalyzed data from Ichikawa (1967) and Hotta and Marui (1976) which were obtained in tests conducted with regular waves, whereas the present tests were conducted with irregular waves. The inverse of the relative depths for the irregular wave data of the present study at which maximum $+U_{r m s}$ occurs ranges between 0.53 and 
0.71. Because irregular waves are used, and breaking is influenced by reflection off the structure and not solely on depth, breaker location occurs over a broader range of relative depths with random waves. Therefore, predictions of maximum bottom rms velocities, and potential scour, must account for structure slope and composition in addition to incident wave height, wave period, and water depth.

If bottom rms velocity is normalized by wave celerity and plotted versus relative depth (Figure 8 ), a slightly more obvious trend is apparent. Figure 8 shows that the greatest horizontal rms bottom velocity is approximately the same for both slopes. Data scatter is considerable for constant values of $d_{s} / H_{i}$. Figures $9 \mathrm{a}$ and $9 \mathrm{~b}$ separate the Figure 8 data according to structure slope, 1:2 and 1:3.5, respectively. The following exponential expression, shown in Fig. ures $9 \mathrm{a}$ and $9 \mathrm{~b}$ as a solid line, was fit through regression analysis to the data of each slope:

$$
\frac{+U_{r m s}}{C}=a e^{-0.57 \frac{d_{s}}{H_{i}}}
$$

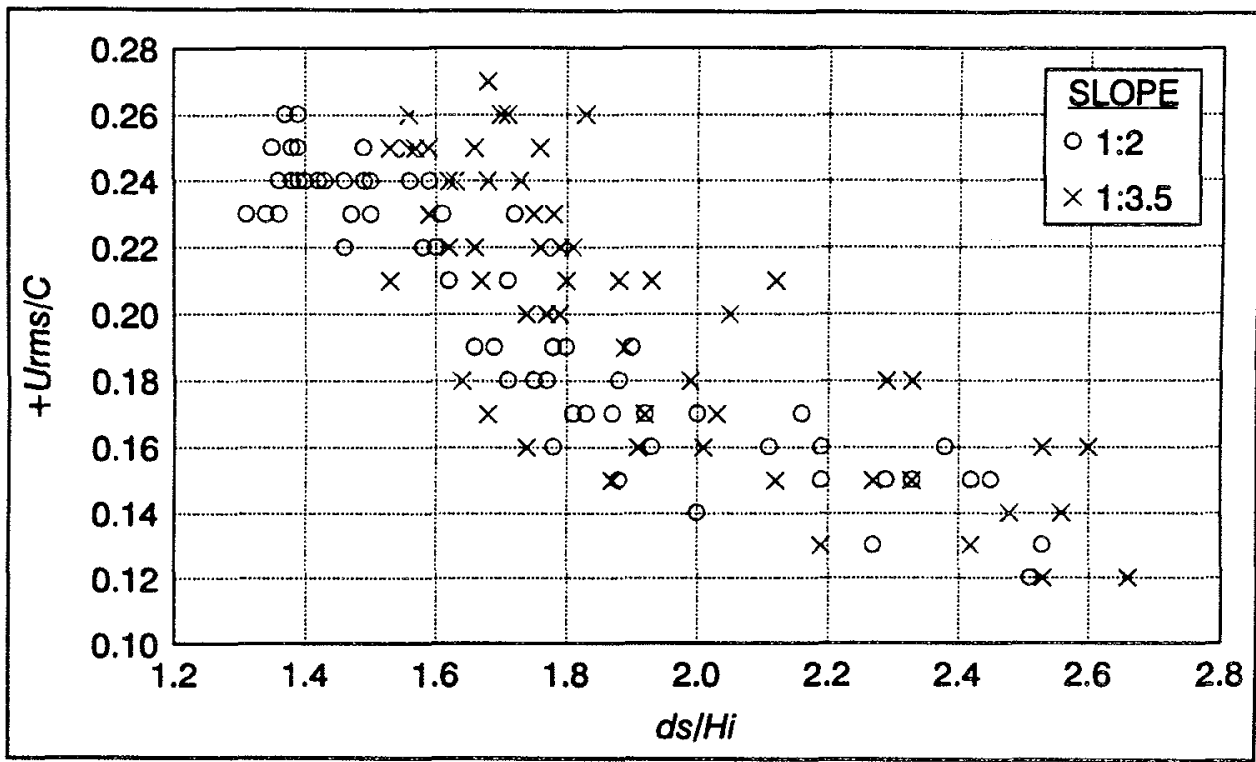

Figure $8 .+U_{r m s} / C$ versus relative depth

The coefficient $a$ was equal to 16.0 for the 1:2 slope revetment and 17.8 for the 1:3.5 slope revetment. Linear interpolation of $a$ between slopes is given by

$$
a=\frac{1.2}{\tan \theta}+13.6
$$




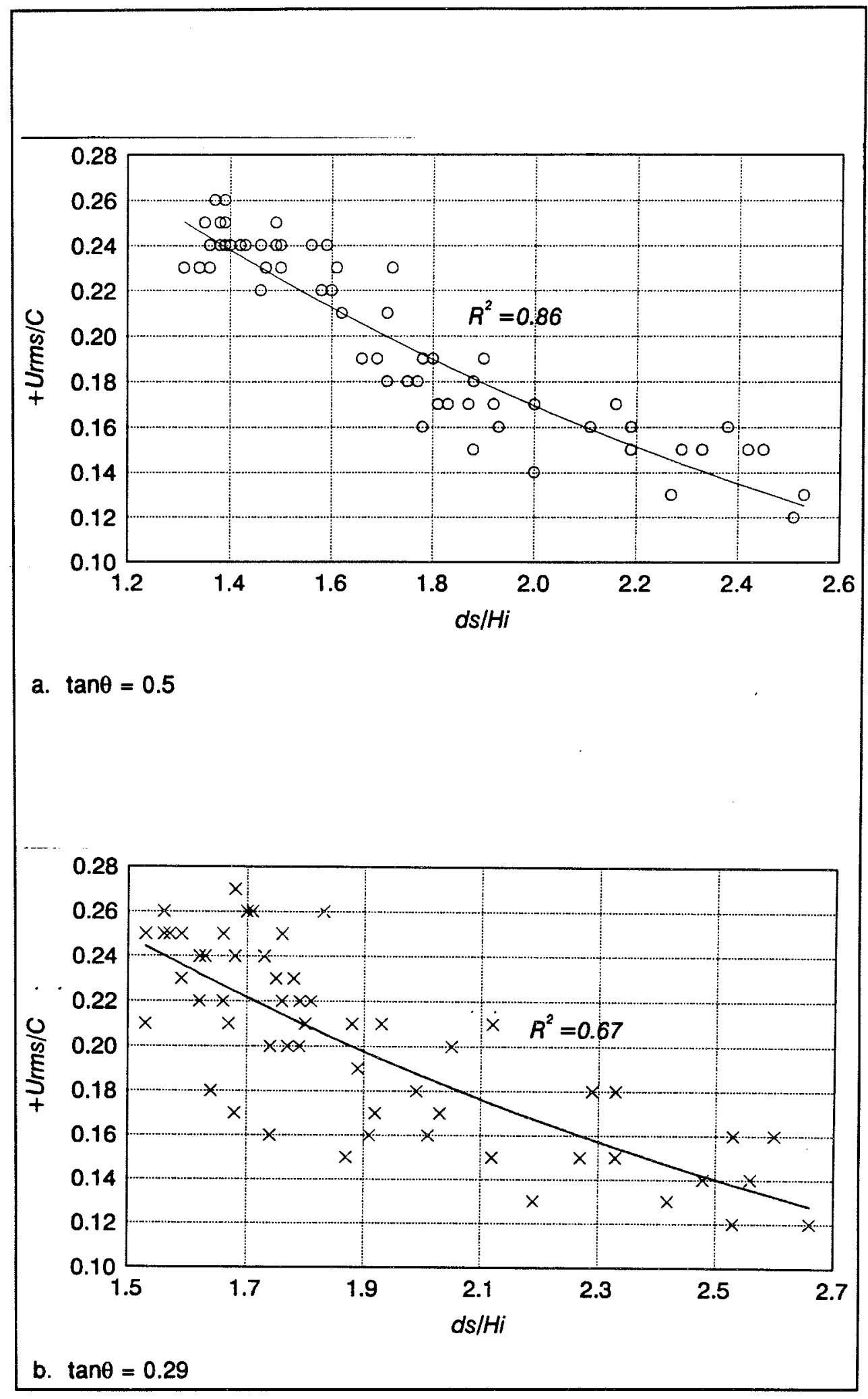

Figure $9 .+U_{r m s} / C$ versus relative depth 
Equations 4 and 5 are based on only two slopes and are valid for $0.29<\tan \theta<0.50$.

It should be noted that measured values of $L$ and $T_{p}$ were used to determine Equation 4. Shallow-water wave theory calculations $C=\left(g d_{s}\right)^{1 / 2}$ may be used if appropriate conditions apply $\left(d_{s} / L<0.04\right)$.

Typically, engineers must design coastal structures with limited wave climate information. To determine how well Equation 4 predicts bottom velocity using only deepwater wave conditions, deepwater wave heights were first transformed to the depth at the structure toe. Smith and Hughes (1993) found that linear (Airy 1845) and Goda (1975) transformations predicted measured values well in front of a reflective structure. Local wave height was calculated using the random wave transformation of Goda. Figure 10 shows that wave heights from the Goda transformation underpredicted and overpredicted measured incident wave heights at the nearshore array. The predicted heights were used as input in Equation 4 to calculate $+U_{r m s}$. Figure 11 shows that $+U_{r m s}$ is not predicted well if deepwater heights are transformed to shallow water. Smith and Hughes stated the transformation models were developed for conditions in which reflection is small, and did not predict location of breaking well for high reflection conditions. To estimate $+U_{r m s}$ from deepwater parameters, wave height transformation models that account for beaches fronting reflective structures are required.

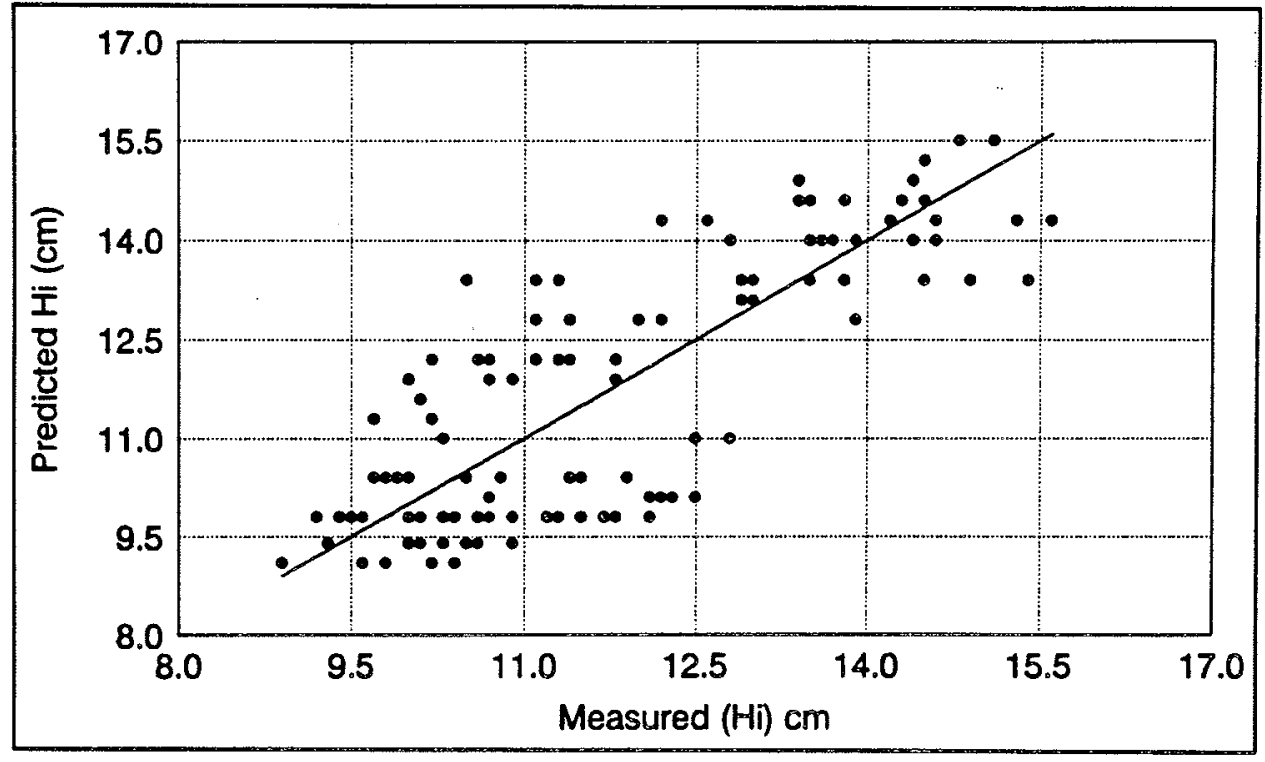

Figure 10. Predicted versus measured nearshore $H_{i}$ using Goda (1975) transformation 


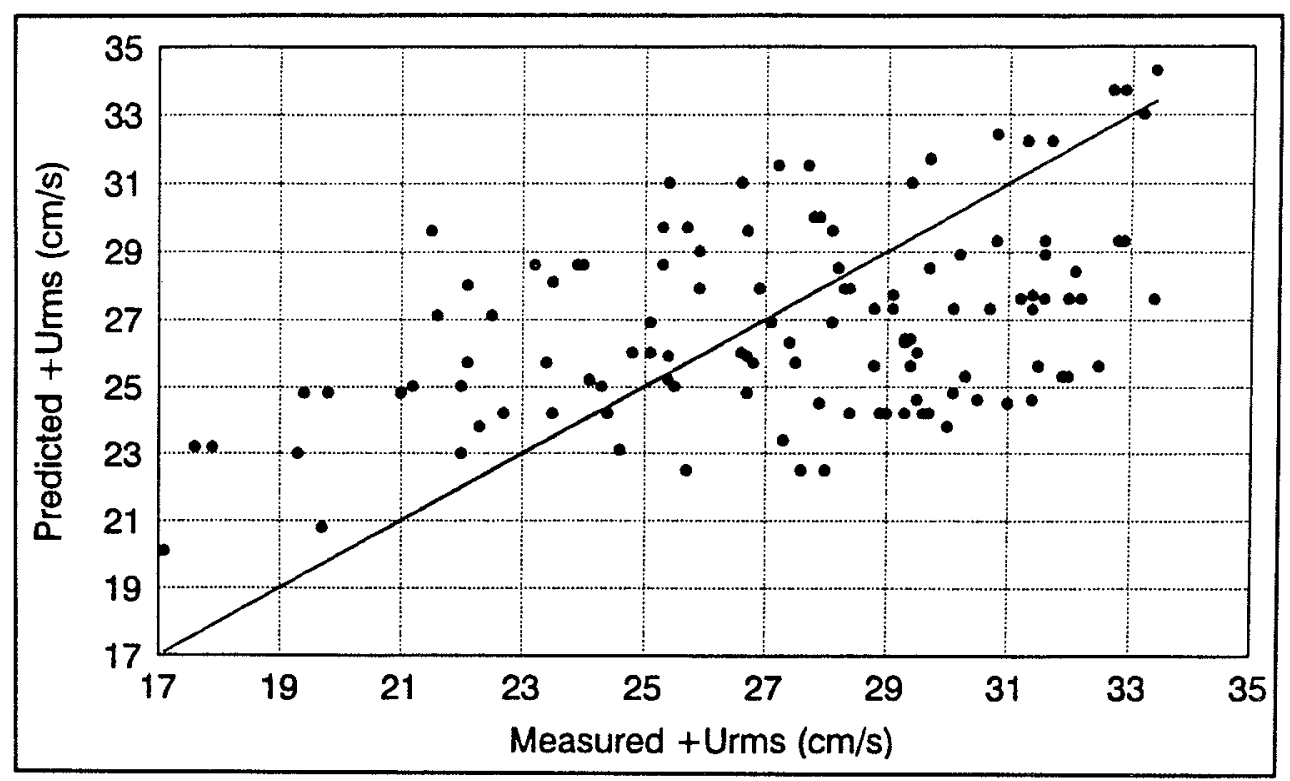

Figure 11. Predicted versus measured $+U_{r m s}$ 


\section{Summary}

An experiment was conducted to determine the wave conditions that have the greatest potential for causing scour at revetments. The assumption was made that maximum scour occurred for a given sediment size where the offshore-directed bottom velocity was maximum. A total of 120 different tests were performed with varying wave height and period, water level, structure slope, and armor layer type. Wave reflection for random waves at revetments also was investigated.

Wave reflection followed the trend of the empirical equation given by Seelig and Ahrens (1981); however, the equation underpredicted measured data from the present study if the coefficients of $\alpha$ and $\beta$ of Seelig and Ahrens or Allsop (1990) were used. Coefficients determined for the irregular wave data were $\alpha=0.54$ and $\beta=1.77$ for conservative predictions, and $\alpha=0.54$ and $\beta=2.95$ for average predictions.

Horizontal bottom velocity increased for increasing reflection coefficients, but at reflection coefficients greater than 0.37 for the $1: 3.5$ and 0.44 for the 1:2.0 slope, $+U_{r m s}$ decreased. The results of the study support the observations of Herbich, Murphy, and Van Weele (1965) that scour ceases at high values of $K_{r}$

Offshore horizontal bottom velocity was inversely proportional to relative depth $d_{s} / H_{i}$, which indicates bottom velocity and scour are greatest for breaking waves. An empirical equation was developed to determine $+U_{r m s} / C$ as a function of $d_{s} / H_{i}$. The equation had good correlation if local wave parameters were used, but predicted bottom velocity less well if local conditions were estimated from deepwater conditions. The effect of the breakpoint location for beaches fronted by a structure could not be determined from the transformation model used. Wave steepness was not a good indicator of $+U_{r m s}$, because bottom velocity is directly proportional to wave height and wave period. 


\section{References}

Airy, G. B. (1845). “Tides and waves," Encyclopedia Metropolitana 192, 241-396.

Allsop, N. W. H. (1990). "Reflection performance of rock armoured slopes in random waves." Proceedings of the $22^{\text {nd }}$ Coastal Engineering Conference. American Society of Civil Engineers, 1460-72.

Chestnutt, C. B., and Schiller, R. E., Jr. (1971). "Scour of simulated gulf coast sand beaches due to wave action in front of seawalls and dune barriers," COE Report No. 139, TAMU-SG-71-207, Texas A\&M University.

Dorland, G. M. (1940). "Equilibrium sand slopes in front of sea walls," unpublished M.S. thesis, Department of Civil Engineering, University of Califomia, Berkeley.

Eckert, J. W. (1983). "Design of toe protection for coastal structures." Proceedings of Coastal Structures '83. American Society of Civil Engineers, $331-41$.

Goda, Y. (1975). "Irregular wave deformation in the surf zone," Coastal Engineering in Japan 18, 13-26.

Goda, Y., and Suzuki, Y. (1976). "Estimation of incident and reflected waves in random wave experiments." Proceedings of the $15^{\text {th }}$ Coastal Engineering Conference. American Society of Civil Engineers, 828-45.

Herbich, J. B., and Ko, S. C. (1968). "Scour of sand beaches in front of seawalls." Proceedings of the $11^{\text {th }}$ Coastal Engineering Conference. American Society of Civil Engineers, 622-43.

Herbich, J. B., Murphy, H. D., and Van Weele, B. (1965). "Scour of flat sand beaches due to wave action in front of sea walls." Proceedings of Specialty Conference on Coastal Engineering. American Society of Civil Engineers, Santa Barbara, California, 705-27. 
Hotta, S., and Marui, N. (1976). "Local scour and current around a porous breakwater." Proceedings of the $15^{\text {th }}$ Coastal Engineering Conference. American Society of Civil Engineers, 1590-604.

Hudson, R. Y. (1961). "Laboratory investigation of rubble-mound breakwaters." Transactions of the American Society of Civil Engineers 126(IV).

Hughes, S. A., and Fowler, J. E. (1995). "Estimating wave-induced kinematics at sloping structures," Journal of Waterway, Port, Coastal, and Ocean Engineering 121(4), 209-15, American Society of Civil Engineers.

Ichikawa, T. (1967). "Scouring damages at vertical wall breakwaters of Tagonoura Port.," Coastal Engineering in Japan 10, 95-108.

Kraus, N. C. (1988). "The effects of seawalls on the beach: An extended literature review," Journal of Coastal Research, Special Issue No. 4, N. C. Kraus and O. H. Pilkey, eds., 1-28.

Lee, T. T. (1970). "Estuary inlet channel stabilization study using a hydraulic model." Proceedings of the $12^{\text {th }}$ Coastal Engineering Conference. American Society of Civil Engineers, 1117-36.

. (1972). "Design of filter system for rubble-mound structures." Proceedings of the $13^{\text {th }}$ Coastal Engineering Conference. American Society of Civil Engineers, 1917-33.

Markle, D. G. (1989). "Stability of toe berm armor stone and toe buttress ing stone on rubble-mound breakwaters and jetties," Technical Report REMR-CO-12, U. S. Amy Engineer Waterways Experiment Station, Vicksburg, MS.

Powell, K. A. (1987). "Toe scour at sea walls subject to wave action; a literature review," Report SR 119, Hydraulics Research, Wallingford.

Russel, R. C. H., and Inglis, C. (1953). "The influence of a vertical wall on a beach in front of it." Proceedings of the Minnesota International Hydraulics Convention. American Society of Civil Engineers, 221-6.

Sato, S., Tanaka, N., and Irie, I. (1968). "Study on scouring at the foot of coastal structures." Proceedings of the $11^{\text {th }}$ Coastal Engineering Conference. American Society of Civil Engineers, 579-98.

Sawaragi, T. (1966). "Scouring due to wave action at the toe of permeable coastal structure," Proceedings of $10^{\text {th }}$ Coastal Engineering Conference. American Society of Civil Engineers, 1036-47. 
Seelig, W. N., and Ahrens, J. P. (1981). "Estimation of wave reflection and energy dissipation for beaches, revetments, and breakwater," CERC Technical Paper 81-1, U.S. Army Engineer Waterways Experiment Station, Vicksburg, MS.

Shore Protection Manual. (1984). $4^{\text {th }}$ ed., 2 Vol, U.S. Army Engineer Waterways Experiment Station, U.S. Government Printing Office, Washington, DC.

Smith, E. R., and Hughes, S. A. (1993). "Shoaling of wave spectra in front of reflective structures." Proceedings of Waves '93. American Society of Civil Engineers, 642-56.

Smith, E. R., and Kraus, N. C. (1991). "Laboratory study of wave-breaking over bars and artificial reefs," Journal of Waterway, Port, Coastal, and Ocean Engineering 117(4), American Society of Civil Engineers, 307-25.

Song, W. O., and Schiller, R. E., Jr. (1977). "Experimental studies of beach scour due to wave action." Proceedings of Hydraulics in Coastal Zone. American Society of Civil Engineers, 328-35.

Xie, S-L. (1985). "Scouring pattems in front of vertical breakwaters," Acta Oceanologica Sinica 4(1), 153-64. 


\section{Appendix A Notation}

$a$

B

C

$d_{b}$

$d_{s}$

$d_{s} / H_{i}$

$g$

$H_{b}$

$H_{d}$

$H_{i}$

$H_{o}$

$H^{\prime}$

$H_{d} L_{o}$

$K_{d}$

$K_{r}$

$k_{\Delta}$

$L$

$L_{o}$
Coefficient in offshore bottom velocity equation

Toe berm width

Wave celerity

Depth at wave breaking

Depth at toe of structure

Relative depth

Acceleration due to gravity

Wave height at breaking

Design wave height at structure

Incident wave height

Deepwater wave height

Wave height in horizontal section of wave tank

Deepwater wave steepness

Stability coefficient

Reflection coefficient

Armor layer coefficient

Local wavelength

Deepwater wavelength 


\begin{tabular}{ll}
$m$ & Beach slope \\
$n_{s}$ & Number of stone widths \\
$S_{r}$ & $\begin{array}{l}\text { Specific gravity of armor unit relative to water in which it } \\
\text { is placed }\end{array}$ \\
$T$ & Wave period \\
$T_{p}$ & Peak wave period \\
$U$ & Average bottom velocity \\
$+U_{r m s}$ & Root-mean square bottom velocity in offshore direction \\
$W$ & Mean weight of stable individual armor unit \\
$W_{t o e}$ & Mean weight of stable individual toe stone \\
$\alpha$ & Coefficient in wave reflection equation \\
$\beta$ & Coefficient in wave reflection equation \\
$\gamma_{b}$ & Breaker depth index \\
$\gamma_{r}$ & Specific weight of armor unit \\
$\theta$ & Slope of structure \\
\hline & Surf similarity parameter
\end{tabular}




\section{REPORT DOCUMENTATION PAGE}

Public reporting burden for this collection of intormation is estimated to average 1 hour per response, including the time for reviewing instructions, searching existing data sources, gathering and maintaining the data needed. and completing and reviewing the collecton of intormation. Send comste Devis Highway, Suite 1204, Artington, VA 22202.4302, and to the Office of Management and Budget, Paperwork Reduction Project (0704-0 188), Washington, DC 20503.

\begin{tabular}{l|l|l|l|} 
1. AGENCY USE ONLY (Leave blank) & 2. REPORT DATE & 3. REPORT TYPE AND DATES COVERED
\end{tabular} \begin{tabular}{l|l} 
May 1996 & Final report
\end{tabular}

4. TITLE AND SUBTITLE

Potential Toe Scour and Wave Reflection at Revetments

6. AUTHOR(S)

Emest R. Smith

\section{PERFORMING ORGANIZATION NAME(S) AND ADDRESS(ES)}

8. PERFORMING ORGANIZATION

U.S. Army Engineer Waterways Experiment Station

3909 Halls Ferry Road

Vicksburg, MS 39180-6199

Miscellaneous Paper

CERC-96-2

9. SPONSORING/MONITORING AGENCY NAME(S) AND ADDRESS(ES)

10. SPONSORING/MONITORING

AGENCY REPORT NUMBER

U.S. Army Corps of Engineers

Washington, DC 20314-1000

\section{SUPPLEMENTARY NOTES}

Available from National Technical Information Service, 5285 Port Royal Road, Springfield, VA 22161.

\begin{tabular}{|l|l}
\hline 12a. DISTRIBUTION/AVAILABILITY STATEMENT & 12b. DISTRIBUTION CODE
\end{tabular}

Approved for public release; distribution is unlimited.

13. ABSTRACT (Maximum 200 words)

This paper presents a method for estimating toe scour potential at a reveted slope as charcterized by bottom velocity. Wave, water level, and structure parameters are considered. Laboratory tests were conducted on a fixed (nonerodible) bottom, and wave and bottom velocity time series were measured near the toe of the revetment. Previous scour studies are reviewed, the laboratory experiment is described, and results are presented to correlate representative bottom velocity with relative depth, wave steepness, and reflection.

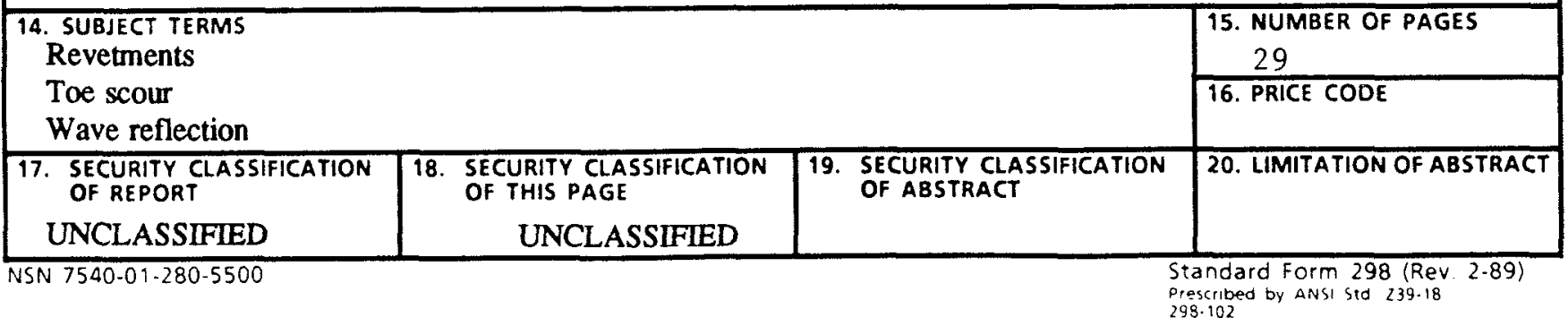

